\title{
Modern Approach towards Clinical Evaluation and Treatment of Alcohol Psychoses
}

\author{
N.A. Aliyev*, Z.N. Aliyev \\ Department of Psychiatry and Addiction, Azerbaijan State Advanced Training Institute for Doctors named by A. Aliyev
}

*Corresponding Author: N. A. Aliyev, Department of Psychiatry and Addiction, Azerbaijan State Advanced Training Institute.

Received Date: September 23, 2021; Accepted Date: September 26, 2021; Published Date: October 30, 2021

Citation Nadir A. Aliyev, Z. N. Aliyev (2021) Modern approach towards clinical evaluation and treatment of alcohol psychoses. J. Addiction Research and Adolescent Behaviour 4(1); DOI: 10.31579/2688-7517/027

Copyright: (C) 2021, N.A. Aliyev, This is an open access article distributed under the Creative Commons Attribution License, which permits unrestricted use, distribution, and reproduction in any medium, provided the original work is properly cited.

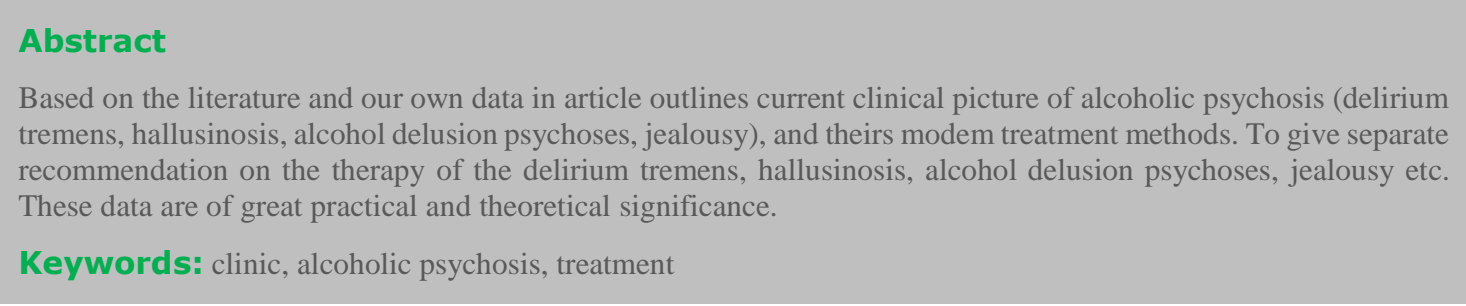

\section{Introduction}

Until now, there is no single classification and approaches to the therapy of alcohol-induced psychotic disorder. Alcohol-induced psychotic disorder in the DSM-5 [1 American Psychiatric Association Diagnostic and statistical manual of mental disorders. 5th ed. American Psychiatric Association, Arlington 2013.] they are described in the section "Schizophrenia Spectrum and Other Psychotic Disorders". There is some evidence in the literature on the clinic and therapy of alcoholinduced psychotic disorder.

The clinic and treatment of alcohol psychosis have been developed based on both the literature [1-14] and our personal experience. These works consider various aspects of alcoholic psychoses: Epidemiology, Treatment of Alcohol-Induced Psychotic Disorder, Wernicke encephalopathy and Korsakoff syndrome, the role of amino acid neurotransmitters in the pathogenesis of alcoholic psychoses and other issues. But the classification and general issues of diagnosis, therapy of certain types of alcoholic psychoses in sufficient volume have not been studied.

The increase in the number of alcohol psychoses is one of the most accurate indicators of the prevalence of alcoholism and the severity of alcohol dependence. The prevalence of alcohol psychosis is closely correlated with the level of alcohol use. Alcohol psychoses occur in an average of $10 \%$ of alcoholics. The higher this rate, the higher the rate of alcohol dependence. When alcohol delirium is not treated properly, 1-2\% of patients die. According to various authors, the mortality rate in alcoholic encephalopathies is $30-70 \%$.

The aim of this research is to develop a classification, a description of the clinic and the treatment of alcoholic psychoses.

\section{Materials and Methods}

In accordance with the Helsinki Declaration of the World Medical Association "Recommendations for doctors engaged in biomedical research involving people", adopted by the 18th World Medical Assembly (Finland, 1964, revised in Japan in 1975, Italy-1983, Hong Kong-1989, the South African Republic-1996, Edinburgh-2000); The Constitution of the Republic of Azerbaijan, the Law "On Psychiatric Assistance" (adopted on 12.06.2001, with amendments and additions11.11.2011. Parents or guardians have provided written informed consent to provide specific anonymized information obtained from their clinic visits for research use and have been reassured that their participation in the study is not related to ongoing clinical care. Consensus and data were obtained as patients were examined over a fiveyear period.

The decision of the Ethical Committee at the Azerbaijan Psychiatric Association on the article of NA. Aliev, ZN. Aliev, "Modern approach towards clinical evaluation and treatment of alcohol psychoses" submitted for publication in psychiatric journals: in connection with compliance with its legislative requirements and regulatory documents is to approve the article by NA. Aliyev, ZN. Aliyev "Modern approach towards clinical evaluation and treatment of alcohol psychoses"

The patients were observed at the Mental Health Center of the Ministry of Health of the Republic of Azerbaijan from January 2017 to January 2021 for 24 months.

All participants received a psychiatric evaluation that included: an interview with the patient (rapport-building, modified mental status exam, observations, and interactions); interview with parents and/or care providers (chief complaint, developmental, educational, psychiatric and medical histories, present illness, review of systems); and a review of collateral information derived from patients' medical records and as needed from teachers, other physicians, or vocational/residential staff. All patients were diagnoses by using ICD-10 and DSM-5 [7]. 


\begin{tabular}{|l|l|}
\hline \multicolumn{1}{|c|}{ Indicators } & Quantity \\
\hline Patients with various forms of alcoholic psychoses - total & 200 \\
\hline Sex, men/women & $175 / 25$ \\
\hline The average age $(18-60)$ years & $35,0 \pm 8,5$ \\
\hline The duration of the disease years & $1,5 \pm 0,5$ \\
\hline Working & 150 \\
\hline Non-working & 40 \\
\hline Disabled persons & 10 \\
\hline
\end{tabular}

Clinical characteristics of enrolled patients was hown in the Table1.

Table 1: Clinical characteristics of enrolled patients

\section{The result of the study}

\section{Etiology and pathogenesis of alcohol psychosis}

The most common of the alcohol psychoses are delirium tremens and hallucinations. Both psychoses occur in the syndrome of alcohol abstinence and at the peak of acute alcohol withdrawal. Before the onset of psychosis, there are often head injuries, acute infectious diseases, acute poisoning (alcohol surrogates, drugs, etc.), as well as somatic pathology and stress. That is why alcohol psychoses are sometimes called "metal alcohol psychoses".

At present, in the development of alcohol psychosis, great importance is attached to internal and external intoxication, disorders of metabolism (mainly CNS neurotransmitters), and the immune system. In fact, alcohol psychoses occur in stages II-III of alcohol dependence on the basis of acute disruption of homeostasis.

With regular use of alcohol, CNS levels return, glutamic acid and dopamine decrease. During abstinence, the opposite happens, that is, the level of GAYT decreases, the amount of glutamic acid, dopamine increases. The activity of other neurotransmitters and neuromodulators (serotonin, acetylcholine, endorphins, various types of channels in neurons, etc. is disrupted, alcohol detoxification function and electrolyte metabolism disorders also play an important role in the development of alcohol psychosis.

In the pathogenesis of alcohol delirium tremens play a major role in metabolic and neurovegetative processes. Damage to the liver impairs its detoxification function, slows down the synthesis of protein fractions and other important compounds in the blood. As a result, toxic damage to the CNS primarily impairs the function of the diencephalon, which controls neurohumoral compensatory mechanisms. Impaired detoxification of the liver slows down the oxidation of alcohol, resulting in the formation of more toxic substances. It is a disorder of electrolyte metabolism that leads to the development of delirium tremens.

Although alcohol is close to the mechanisms in delirium tremens in the development of encephalopathies, disorders of vitamin metabolism (especially B1, B6 and PP deficiency) are of particular importance in the former. Among the exogenous factors, traumatic brain injury and chronic somatic diseases play an important role.

The pathogenesis of alcohol hallucinations and delusional psychoses is unclear.

\section{Clinical forms of alcohol psychosis}

From a clinical point of view, they are divided into acute, chronic (persistent) and chronic variants. Due to the predominance of this or that psychopathological syndrome in the clinical picture, delirium, hallucinations, delirium, etc. are divided. One of the characteristics of alcohol psychosis (AP) is the phase-like nature of clinical manifestations in its development, often these clinical manifestations combine to form a picture of polymorphism (ie, psychotic disorders are either interchangeable or occur simultaneously).

One form of mixed AP is observed with another form (for example, delirium tremens is manifested by symptoms characteristic of hallucinations or paranoia).

The main form of atypical AP is found in conjunction with endoform disorders (e.g., oneroid thinking disorder or mental automatism).

During complex AP, one psychosis is successively replaced by another, for example, delirium tremens with hallucinations, hallucinations with paranoia, and so on.

In modern therapy, the duration of treatment for alcoholic delirium tremens does not exceed 8-10 days. Alcohol hallucinations and delusional psychoses are called acute if they disappear within a month, and longlasting if they last up to 6 months.

$\mathrm{AP}$ is divided according to the type of travel: transitor - one-time; recurrent - recurrent two or more times after remission; mixed - transient or recurrent departure, replaced by chronic psychotic conditions; continuous - chronic psychosis that progresses periodically after acute psychosis or independently.

Types of alcohol psychosis: 1) alcohol delirium tremens; 2) alcohol hallucinations; 3) psychosis of alcoholism; 4) alcoholic encephalopathies; 5) less common forms of alcohol psychosis.

\section{Delirium tremens.}

Definition - delirium syndrome observed in stages II-III of alcohol dependence and acute alcohol psychosis characterized by expressive somato-vegetative, neurological disorders.

Clinical picture. Usually alcohol delirium tremens develops at the peak of AAS (maximum 2-4 days), usually in the evening or at night. Early symptoms: anxiety, indecision, acute anxiety and persistent insomnia Increased signs of arousal of the sympatho-adrenaline system - pale skin, tachycardia, arterial hypertension, hyperhidrosis, and mild hyperthermia. Vegetative disorders - ataxia, muscle hypotension, hyperreflexia, tremors. Disorders of fluid-electrolyte balance (thirst, hyperazotemia, metabolic acidosis), changes in the blood picture (leukocytosis, accelerated erythrocyte sedimentation rate, increased bilirubin, etc.).

Vegetative and neurological symptoms appear before the disorder and persist for a long time. Paradolic illusions are then added to the signs. The illusion of perception is soon replaced by visual hallucinations.

Etiology. The main causes: severe and long-term addiction, the use of alcohol surrogates, acute somatic pathology, organic brain damage, etc. The pathogenesis of alcohol delirium tremens is not fully understood. The CNS plays a major role in the exchange of neurotransmitters and, above all, in severe endogenous intoxication.

\section{Differential diagnosis}




\begin{tabular}{|l|l|l|}
\hline & $\begin{array}{l}\text { Delirium tremens during alcohol } \\
\text { dependence }\end{array}$ & Delirium tremens in intoxications \\
\hline Anamnesis & $\begin{array}{l}\text { Long-term alcohol abuse, signs of } \\
\text { alcohol dependence }\end{array}$ & $\begin{array}{l}\text { Epidemiological history, early signs of infectious } \\
\text { disease. surgical pathology, abuse of psychoactive } \\
\text { substances (stimulants, volatile solvents, } \\
\text { cholinolytics) }\end{array}$ \\
\hline Clinical data & $\begin{array}{l}\text { Absence of symptoms: Intoxication } \\
\text { from psychoactive substances, } \\
\text { infectious diseases, surgical } \\
\text { pathology, fever }\end{array}$ & $\begin{array}{l}\text { Symptoms of substance intoxication, infectious } \\
\text { diseases, acute surgical pathology. } \\
\text { temperature high }\end{array}$ \\
\hline Laboratory data & $\begin{array}{l}\text { Symptoms of alcohol damage to the } \\
\text { liver (increased levels of liver } \\
\text { enzymes), chronic intoxication } \\
\text { (erythrocyte sedimentation rate, } \\
\text { relative leukocytosis) }\end{array}$ & $\begin{array}{l}\text { Determination of psychoactive substances in } \\
\text { biological materials, } \\
\text { detection of an infectious agent, signs of surgical } \\
\text { pathology (eg, high levels of amylase in acute } \\
\text { pancreatitis) }\end{array}$ \\
\hline
\end{tabular}

Table 1 Differential diagnosis of alcohol and intoxication delirium tremens

Forms of reduced alcohol delirium tremens. When you close your eyes while lying down for hypnogic delirium, your vision is hallucinatory, resembling a large number of bright scenes. The content of the hallucinations is frightening (for example, running after danger). Criticism of what they see when they open their eyes does not quickly develop, and this situation affects the behavior and speech of patients. Usually hypnagogic delirium tremens lasts 1-2 nights, and then can progress to other forms of alcohol psychosis.

Hypnagogic delirium tremens with a fantastic content differs from the above in that they alternate with fantastic, physically bright visual hallucinations, stage-like hallucinatory disorders. Interestingly, when the patient opens his eyes, the fantasy disappears, and when he closes his eyes, it reappears. There is no guide to the environment.

Delirium tremens without delirium tremens (lucid delirium tremens, tremor syndrome) F 10.44 - as an atypical form, there are no hallucinations or delusions in the clinical picture. The most acute neurological disorders come to the fore: clear, rough tremors, ataxia, sweating. Guidance on the environment and time is temporary. Effects of fear and anxiety are constant. The duration of this type of delirium tremens is 1-3 days, and recovery often occurs critically. It is possible to pass another form of delirium tremens.

Abortive delirium tremens (F 10.46) usually do not have predromal manifestations. Individual visual illusions and microscopic hallucinations, acoasms, phonemes are observed in the clinical picture. Affectfulness and fear are the same as delirium-like disorders of thought. The duration of abortive delirium tremens is 1 day. Healing is critical.

Typical or classic alcohol delirium tremens. In the typical alcohol delirium tremens, the symptoms go away with tremors from a few hours to a day, then the hallucinations become permanent. Alcohol delirium tremens goes through several stages in its development.

Prodromal stage this stage, which lasts several days, is mainly dominated by sleep disorders (terrible, nightmares, fear).

Stage I. The mood disorders in the prodorm of the disease become more prevalent and are replaced by the opposite affect: frustration, anxiety or fear are easily replaced by euphoria, unreasonable joy, Patients talk a lot, become indecisive. Facial expressions and movements come to life, change often. Sometimes, when time and space are violated, self-direction is maintained. Emotional and psychomotor arousal, frequent changes in affect, and delirium tremens are of differential diagnostic importance to distinguish them from the predominant variant of the AS mental component. Unlike the initial stage of delirium, the hangover is a kind of depression and excitement.

Phase II. The paradigm is added to the clinical picture of the first stage - fantastic visual illusions. They can be black and white or colored, static or dynamic. Hypnotic hallucinations of varying intensity are characteristic. As before, sleep is intermittent (intermittent) with nightmares. When the patient wakes up, he cannot immediately separate sleep from reality. As hyperesthesia intensifies, fear of light increases. Sleep-like manifestations are mixed with wakefulness, numbness is observed.

Stage III. In the third stage, complete insomnia and true visual hallucinations occur. Zoological (insects, small rodents, etc.), tactile (feeling of hair or stalk in the mouth) hallucinations, and sometimes frightening auditory hallucinations are possible. If the guide to time and space is violated, the guide itself is preserved. In addition to the continuity of affective disorders, fear, anxiety, and confusion predominate. At the top of the delirium tremens the patient becomes an interesting spectator. In the deepening of delirium tremens, hallucinations of hearing, smell, thermal, tactile, general sensation occur. The feeling of time changes - for the patient, time either lengthens or shortens. The patient's behavior, affect, ideas of delusion correspond to the content of hallucinations. Because of the predominance of fear, patients want to run away, hide, go somewhere, throw something at themselves, and turn to false (fictitious) interlocutors. His attention is very distracted, his mood is changeable, and his facial expressions are expressive. Illusion is unsystematic during delirium tremens, reflects the content of hallucinations, mainly persecution, physical destruction, and sometimes jealousy. Patients have high instincts (Aschaffenburg, Lipman, Reichard, Bechterew's symptoms). It is possible to reduce the symptoms of psychosis by focusing on something else (talking to a doctor, medical staff). Typical alcohol delirium tremens can be observed in stage III (lucid) period. In this case, significant asthenic disorders are observed in patients. In the evening and at night, hallucinatory and delusional disorders intensify, psychomotor arousal increases, and anxiety can develop up to raptus.

Every so-called symptoms of soporosis go to sleep. In many cases, this ends the development of delirium tremens. Exit from psychosis is either critical (after a long deep sleep) or lytic (slow: the symptoms are a wave of reduction, psychopathological symptoms increase for a while with a less intense level, and then decrease. The end of delirium tremens will be accompanied by an asthenic reaction. .The duration of delirium tremens usually occurs on average 2-8 days. 
Alcohol delirium tremens mixed form. Alcohol delirium tremens can be complicated by the structure: it is possible to combine the ideas of selfblame, harm, attitude, and persecution delusion. Hallucinations are more complex, stage-like (domestic, art. Sometimes religious, war scenes depicting either military life or in a fantastic plan). Mixed delirium tremens are divided into systemic and acutely expressed hallucinatory forms. These forms are not intended for XBT-10.

Systematized delirium tremens does not differ from typical delirium tremens in stages I and II. In stage III, stage-like visual hallucinations predominate. According to the content, there are more scenes of persecution and assassination. The patient's behavior is related, that is, the patient wants to run away and find a safe place. The fear affect is persistent and expressive. The idea of delusion is inextricably linked to the content of hallucinations. The duration of psychosis can be several days, several weeks or more. Delirium tremens, which is accompanied by acute verbal hallucinations, is always accompanied by verbal hallucinations instead of intense visual, thermal, tactile, visual illusions.

Severe delirium tremens. Severe delirium tremens can be fatal, characterized by acute somatovegetative, neurological, and psychopathological symptoms. Severe delirium tremens are divided into two types - professional and humming.

Professional delirium tremens (delirium tremens F10.43 with professional delirium) Psychosis begins with typical disorders, the clinical picture changes to aggravation. In this case, the intensity of hallucinatory disorders is low, weakened or the idea of persecution disappears. Affective disorders are monotonous. Behavioral disorders are limited in scope and stereotypical. Patients perform their usual actions, including those specific to their art (dressing, undressing, counting money, signing papers, washing dishes, ironing, etc.).

Self-guidance is maintained. The appearance of signs of constipation during the day indicates the aggravation of the condition. Professional delirium tremens is usually accompanied by complete amnesia. When professional delirium tremens worsens, a humming delirium tremens occurs.

Humming delirium tremens - F10.42. Humorous delirium tremens is often associated with occupational delirium tremens, and in some cases with poor autochthonous or intercurrent disease. Humming delirium tremens often develop quickly, over several hours or days, with virtually no hallucinatory or delusional ideas. For this condition, there is a profound disturbance of thinking (darkening), special disorders in the motor area and somatoneurological changes. Motor awakening occurs at the border of the bed - catch, pull, straighten wrinkles, collect, and fold (carthalogia). Sometimes contraction of individual muscles, choreoform hyperkinesis is noted. Awakening of speech consists of separate simple words, syllables, modulated, quiet sounds. Symptoms of stagnation worsen and are observed both at night and during the day. Recovery is possible, but the whole period of psychosis is amnesia. It should be noted that neurological and autonomic disorders occupy a leading position in the clinical picture of humoral delirium tremens. At this time, vegetative disorders such as tachycardia, frequent changes in AT, a drop in blood pressure, which often leads to collapse, hyperhidrosis, oliguria (anuria), subcutaneous hematomas, hyperthermia $\left(40-41^{\circ} \mathrm{C}\right)$, shortness of breath occur.

Neurological symptoms: ataxia, asthma, hyperkinesis, signs of oral automatism, impaired muscle tone, stiffness of the neck muscles, urinary and fecal incontinence (undesirable, bad sign). As the disease progresses, the clinical picture is dominated by amentive-like disorders, speech and motor incoherence.

Atypical delirium tremens. The clinical picture of atypical delirium tremens includes psychotic conditions associated with endogenous process (schizophrenia). In this case, delirium tremens are accompanied by symptoms, mental automatism or oneroid-type disorders of thinking. Atypical delirium tremens often occur after recurrent psychoses. Since XBT-10 does not address this syndrome, it should be classified as an abstinence syndrome complicated by delirium tremens (F10.48).

Fantastic delirium trem (fantastic delirium tremen, alcohol oneeroid, oneeroid delirium tremen). In the prodromal stage of the disease, numerous photopsies, acoasms, elementary visual hallucinations, episodes of physical delusions predominate. The development of alcoholic oneroid is accompanied by a complication of the clinical picture of the disease.

Psychosis can start as a fantastic hypnosis or classic delirium tremens. On days 2-3 of psychosis, the clinical picture is usually complicated at night: stage-like visual and auditory hallucinations occur, fantastic delusions, movement awakening is replaced by coordinated movements, irregular, chaotic.

The content of the hallucinations is fantastic, there are scary scenes - war, disaster. When you open your eyes, the patient becomes a spectator, and when you close your eyes, you become a participant. At this time, patients often feel a sense of displacement in space. When stage-like visual hallucinations predominate in the clinical picture, general drowsiness and inactivity increase. This condition is reminiscent of a substupor or stupor condition. Gives short answers to questions after numerous repetitions, despite the braking condition. As in other forms of delirium tremens, here the guide to space and time is lost, but preserved. The patient's facial expressions are the same as in oneiroid: frozen, frozen facial expressions are replaced by scary, anxious, surprised, amazed facial expressions. At the beginning of psychosis, the fear affect prevails. As the clinical picture becomes more complex, fear disappears and is replaced by curiosity, surprise, and indifference.

The duration of psychosis lasts from a few days to a week. Recovery after deep sleep is critical. Impressions of the disease are remembered for a long time. Residual delirium persists for some time after psychosis.

Delirium tremens with onerism disorders (alcohol onerism). Compared to oneiroids, the disorder is not deep, and the illusion-delusion component is less expressive. Pre-hallucinations are bright. Onerism does not have pseudo-hallucinations and mental automatism. Psychosis critically ends after 6-7 days of deep sleep.

Delirium tremens with mental automatism. Typical or systemic delirium with mental automatism occurs at the peak of tremens. Automatism is transient, incomplete, and occurs in all its forms - ideator, sensor, motor. The three types of automatism are never found together. During the reduction of delirium tremens, first of all, automatism disappears. The duration of psychosis is $1.5-2$ weeks. The speech is critical. It is possible to form a residual delusion in the lytic speech.

Alcohol hallucinations. Alcohol hallucinations are the occurrence of verbal hallucinations in alcoholics with delusions of persecution.

Clinical picture. Acute verbal hallucinations begin with anxiety, fear, anxiety-type affective, and sleep disturbances. Against this background, hallucinations appear in the form of separate sounds, words, phrases. Patients usually pinpoint the exact location of the sounds. Hallucinations are accompanied by an astonishing effect of motor anxiety. Mental and affective disorders often disappear after deep sleep. The subsequent development of psychosis manifests a large number of verbal hallucinations, secondary delusional ideas (attitude, influence, blame, persecution or physical destruction) associated with them. Patients are extremely prone to fear and panic, very suspicious. After treatment, patients become critical of their experiences, and depression and asthenic conditions remain. Impressions are gained in a fluid, global, diffused way. 
Etiology. Alcoholic hallucinations develop 10-14 years after the onset of alcohol dependence syndrome and long-term systemic alcohol intoxication.

\section{The pathogenesis is unknown.}

Differential diagnosis. All types of alcohol hallucinations should be differentially diagnosed with schizophrenia complicated by alcoholism.
Hallucinoses are classified according to their main clinical symptoms, such as delirium tremens - according to the course and manifestations of psychopathological features. According to the clinical picture, hallucinations are divided into typical or classical, reduced, mixed and atypical forms.

\begin{tabular}{|c|c|}
\hline Hallucinations during alcohol dependence & Hallucinations in schizophrenia aggravated by alcoholism \\
\hline $\begin{array}{l}\text { Typical "alcohol" history, first clinical picture of } \\
\text { alcoholism }\end{array}$ & $\begin{array}{l}\text { The clinical picture of alcoholism is fragmentary. } \\
\text { Features of the "alcohol" anamnesis: } \\
\text { - early manifestations of altered forms of intoxication; } \\
\text { Features of hangover syndrome - the predominance of mental } \\
\text { components over somatovegetative }\end{array}$ \\
\hline $\begin{array}{l}\text { The first psychosis occurs at least 5-7 years after the } \\
\text { formation of hangover syndrome } \\
\text { Before the development of primary psychosis } \\
\text { long-term alcohol excretion (waste) }\end{array}$ & $\begin{array}{l}\text { Psychosis can occur even before the onset of intoxication hangover } \\
\text { syndrome Alcohol excretion (waste) is short - a few days }\end{array}$ \\
\hline $\begin{array}{l}\text { The development of autochthonous depression in } \\
\text { remission is not characteristic }\end{array}$ & $\begin{array}{l}\text { Autoxuton depressive and subdepressive changes in remissions of } \\
\text { different duration }\end{array}$ \\
\hline $\begin{array}{l}\text { Verbal hallucinations are in the nature of the character } \\
\text { and are located at a distance from the hearing (behind } \\
\text { the wall, behind the door, etc.). }\end{array}$ & $\begin{array}{l}\text { Verbal hallucinations are strange, located outside the auditory canal or } \\
\text { in any part of the body; also happens. }\end{array}$ \\
\hline $\begin{array}{l}\text { Catatonic disorders are not character } \\
\text { Patients' behavior is explained, } \\
\text { hallucinatory manifestations }\end{array}$ & $\begin{array}{l}\text { Their actions and behavior are unusual, they do not come from } \\
\text { hallucinatory manifestations }\end{array}$ \\
\hline
\end{tabular}

Table 2. Differential diagnosis of alcohol hallucinations with schizophrenia aggravated by alcoholism

\section{Reduced acute alcohol hallucinations.}

Acute hypnogic verbal hallucinations. After waking up, these manifestations disappear. Affect manifests itself in the form of frustration and excitement. The duration of psychosis does not exceed a few days. Keep in mind that hypnogogic hallucinations can be replaced by more complex expanded hallucinations.

Acute abortive hallucinations. May be limited to neutral verbal hallucinations. When the psychopathological structure of hallucinations is complicated, their content can be frightening, blaming, imperative, aimed at the patient. Anxiety, fear affect, behavior changes, motor arousal increases, criticism of the manifestations disappears. Such psychoses last from a few hours to a day. Exit from psychosis is critical. Sometimes abortive hallucinations are an earlier stage of extended hallucinatory psychosis.

Acute hallucinations (classic). Acute alcohol hallucinations occur against the background of hangover disorders and are accompanied by signs of anxiety, paranoid mood, and autonomic disorders. However, hallucinations can develop after prolonged, daily intoxication, accompanied by insomnia.

The symptom complex of acute alcohol hallucinations consists of real auditory hallucinations, their delusional explanation, fear affect.

The onset is usually acute. Anxiety, excitement, mood swings, dizziness, etc. can occur within a few weeks in advance. Can be. Psychosis begins in the evening or at night. Sleep is disturbed, fear affects the mood, they wake up quickly after going to sleep, and the patient sweats a lot. At first, auditory hallucinations are simple. Then the monologue, the dialogue, and finally the polyvocal verbal hallucinations are rapidly replaced by scenes that alternate around a single theme. Votes are usually addressed as a third party. The nature of the voices is threatening, blaming, punishing, reprimanding, and so on for the patient. Happens on the subject. Some voices defend the patient, others blame. The events discussed by the voices are related to real events that have taken place with the patient in the past or present. The idea of delusion is clearly related to the content of hallucinations. Then, when the anxiety increases, patients try to flee in self-defense, build barriers, close the ward door behind them, and so on. In the next stage, the patient becomes the one who is being persecuted. In alcohol hallucinations, unlike delirium tremens, time and space are guided. Alcohol hallucinations do not impair memory or confabulation. Psychosis is usually critical after deep sleep. The duration of acute alcohol hallucinations is from a few days to 4 weeks.

Mixed acute alcohol hallucinations: 1) Verbal hallucinations of a less frightening nature are characterized by the presence of acutely expressed hallucinations. 2) Coexistence of acute hallucinations with delirium tremens - delirium tremens disorders develop at each stage of hallucinations, mainly at night.

Atypical acute alcohol hallucinations. The clinical picture of acute alcohol hallucinations is characterized by oneroid-type thinking disorders, mental automatism, or depressive symptoms.

Semi-acute alcohol hallucinations. The duration of subacute alcohol hallucinations is from 1 to 6 months (average 2-3 months). According to the predominance of one or another psychopathological symptoms in the clinical picture of subacute alcoholic hallucinations, there are three variants: 1) Subacute alcoholic hallucinations with the predominance of verbal hallucinations. 2) Semi-acute alcohol hallucinations with a predominance of depressive affect. 3) Semi-acute alcohol hallucinations with predominance of delusions.

Chronic alcohol hallucinations. Chronic alcohol hallucinations are a rare disease. The clinical picture of chronic alcoholic hallucinations is divided into several variants according to the predominance of one or another psychopathological symptoms: 1) Chronic alcoholic hallucinations without delirium. The course of chronic alcoholic hallucinations without dementia is stationary and does not lead to mental retardation and personality decline. 2) Chronic alcohol hallucinations 
observed with delirium. 3) Chronic alcohol hallucinations accompanied by paraphrenic changes of mental automatism and delusions.

Alcohol delusional psychoses. Clinical manifestations of alcoholic delusional psychoses are characterized by polymorphic, extreme instability, mobility, dynamism, sensitivity to endogenous and exogenous influences of psychopathological symptoms. There are several variants of alcohol delusional psychoses - alcohol paranoid and marital jealousy (infidelity, infidelity) delusions.
Alcohol paranoid - is a severe bright delusional psychosis characterized by fear affect. Acute alcohol paranoia is manifested by delusions of physical persecution, anxious-depressive affect, ideas of special meaning, physical impact. Alcohol paranoids are divided into abortive, acute, and schizophrenic-like variants. It is necessary to dwell on the differential diagnosis between alcohol paranoid and paranoid syndrome of schizophrenia aggravated by alcohol dependence syndrome. The following table provides their differential diagnosis.

\begin{tabular}{|l|l|}
\hline Alcohol paranoid & $\begin{array}{l}\text { Paranoid schizophrenia aggravated by alcohol dependence } \\
\text { syndrome }\end{array}$ \\
\hline $\begin{array}{l}\text { Extensive clinical picture of pre-existing alcoholism. } \\
\text { Exacerbation of alcoholism before the formation of } \\
\text { delusions }\end{array}$ & $\begin{array}{l}\text { There is no clinical picture of alcoholism. Abstinence } \\
\text { syndrome is fragmentary or absent. Systematic alcohol } \\
\text { intake is rare. }\end{array}$ \\
\hline $\begin{array}{l}\text { There is no dissociation in behavior, long-term } \\
\text { antisocial behavior, family quarrels and conflicts }\end{array}$ & $\begin{array}{l}\text { If behaved, there is dissociation: emotional manifestations } \\
\text { do not correspond to actions. Conflict and conflict are rare. }\end{array}$ \\
\hline $\begin{array}{l}\text { There is no isolation, no distance from people, no } \\
\text { emotional coldness. Rudeness and egocentrism usually } \\
\text { prevail. Sexual harassment, cruelty to the object of } \\
\text { jealousy. }\end{array}$ & $\begin{array}{l}\text { Constant emotional tension, mistrust, suspicion, } \\
\text { accompanied by inappropriate (inadequate) emotional } \\
\text { coldness towards spouse and children }\end{array}$ \\
\hline $\begin{array}{l}\text { Imagination is limited, specific (mainly persecution } \\
\text { and / or jealousy), always arises from understandable } \\
\text { relationships and depends on the external situation. }\end{array}$ & $\begin{array}{l}\text { Imagination is polymorphic diffuse, often transformed, } \\
\text { meaningless. nonsense and difficult to understand, } \\
\text { ambiguity is a character }\end{array}$ \\
\hline $\begin{array}{l}\text { Organic personality change (emotional alertness, } \\
\text { agility, alcoholic humor, and understanding.) }\end{array}$ & $\begin{array}{l}\text { Specific disorders of thinking. Subsequent increase in } \\
\text { productive and negative symptoms. Outcome - a specific } \\
\text { schizophrenic disorder }\end{array}$ \\
\hline
\end{tabular}

Table 3. Differential diagnosis of alcohol paranoid, paranoid syndrome of schizophrenia aggravated by alcohol dependence syndrome Alcohol paranoid Paranoid schizophrenia aggravated by alcohol dependence syndrome

Alcohol jealousy delusion (synonyms: marital infidelity, alcohol paranoia).The definition of chronic alcoholism as dementia psychosis is primary paranoid delusions. It is more common in men only. It should be noted that alcohol paranoia does not include pathological erotic manifestations in the structure of acute delirium tremens and alcohol hallucinations, as well as marital infidelity. They also do not belong to this form of psychosis, or residual jealousy of different duration after other types of psychoses.

Etiology - long-term alcohol dependence, organic damage to the CNS. The pathogenesis is unknown.

\begin{tabular}{|c|c|}
\hline Conditions & Recommended treatments \\
\hline \multirow[t]{4}{*}{$\begin{array}{l}\text { Delirium tremens first, the } \\
\text { prodromal period of acute } \\
\text { alcohol encephalopathy }\end{array}$} & $\begin{array}{l}\text { Therapy is mainly aimed at reducing intoxication, correction of electrolyte disturbances and improving } \\
\text { the rheological properties of the blood: plasmapheresis (20-30\% of circulating blood); povidone } 5 \mathrm{~g} 3 \\
\text { times a day, diluted in water; isotonic solution of sterofundin } 500 \mathrm{ml} \text {, or } 400 \mathrm{ml} \text { of disol; L00-150 ml of } \\
\text { potassium chloride solution. intravenously, in the form of drops (in hypokalemia, adequate diuresis): } \\
\text { dextran (rheopolyglucin) } 200-400 \mathrm{ml} \text { in the form of intravenous drops }\end{array}$ \\
\hline & $\begin{array}{l}\text { Psychomotor arousal and sleep disturbances should be directed to: up to } 60 \mathrm{mg} \text { per day } 0.5 \% \text { diazepam } \\
\text { solution in } 2-4 \mathrm{ml} \text { intramuscularly or intravenously in the form of drops: } 1-2 \mathrm{ml} 0.1 \% \\
\text { bromodihydrochlorphenylbenzodiazepine solution intramuscularly or intravenously maximum dose } \\
0.01 \mathrm{~g} / \text { day, }\end{array}$ \\
\hline & $\begin{array}{l}\text { Vitamin therapy; } 5 \% \text { solution of thiamine (vitamin B) } 4 \mathrm{ml} \text { intramuscularly: pyridoxine (vitamin BG) } \\
5 \% \text { solution } 4 \mathrm{ml} \text { intramuscularly: } 1 \% \text { nicotinic acid (vitamin PP) } 2 \mathrm{ml} \text { intramuscularly: } 5 \% \text { ascorbic } \\
\text { acid (vitamin C)) } 5 \mathrm{ml} \text { intravenously: cyanocobalamin (vitamin B, 2) } 2 \mathrm{ml} \text { intramuscularly. } \\
\begin{array}{l}\text { Neurometabolic therapy: semax - } 2-4 \text { drops in } 0.1 \% \text { solution in the nose or } 0.5 \mathrm{~g} \text { of hopanten acid } 3 \\
\text { times a day, }\end{array}\end{array}$ \\
\hline & Hepatoprotectors: ademethionine $400 \mathrm{mg}$ 1-2 times a day: thioctic acid (espalipone) $600 \mathrm{mg}$ once a day. \\
\hline $\begin{array}{l}\text { Opened delirium tremens, } \\
\text { acute alcohol encephalopathy }\end{array}$ & $\begin{array}{l}\text { Patient fixation. Infusion therapy in the amount of } 40-50 \mathrm{ml} / \mathrm{kg} \text { under the control of electrolyte balance, } \\
\text { blood acid-base balance, plasma glucose and diuresis, diuretics, insulin are prescribed if necessary. } 1.5 \% \\
\text { meglumine sodium succinate (reaberin) in the form of } 400-800 \mathrm{ml} \text { intravenously, } 4-4.5 \mathrm{ml} / \mathrm{min}, 2-3 \\
\text { days or } 200-400 \mathrm{ml} \text { of } 5 \% \text { glucose solution in the form of } 20-40 \mathrm{ml} \text { of cytoflavin Intravenously, at a rate } \\
\text { of } 4-4.5 \mathrm{ml} / \text { minute, } 2-3 \text { days, dextran (reopoliglyukin) } 200-400 \mathrm{ml} / \text { day, stero-fundin, acesol, disol. } \\
\text { Prevention of hypoxia and swelling of the brain: } 10 \% \text { solution of } 10 \% \text { meldonium once a day or } 5 \% \\
\text { solution of mexidol } 2 \mathrm{ml} 2-3 \text { times a day, } 25 \% \text { solution of magnesium sulfate, } 10 \mathrm{ml} \text { twice a day }\end{array}$ \\
\hline
\end{tabular}




\begin{tabular}{|c|c|}
\hline & $\begin{array}{l}\text { Short-acting barbiturates in psychomotor arousal, convulsions [pental sodium, hexobarbital (hexonal) } \\
\text { in the form of drops intravenously up to } 1 \mathrm{~g} / \text { day under constant monitoring of respiration and blood } \\
\text { circulation] }\end{array}$ \\
\hline & Oxygen therapy or hyperbaric oxygenation \\
\hline & Symptomatic treatment of somatic complications \\
\hline 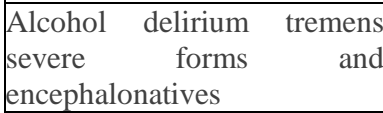 & $\begin{array}{l}\text { Monitoring of vital organs (respiration, heartbeat, and diuresis), acid-base balance, potassium, sodium. } \\
\text { Determination of the level of glucose in oanm olazmasm }\end{array}$ \\
\hline \multirow{6}{*}{$\begin{array}{l}\text { Gaye-Vemike and othe } \\
\text { severe forms }\end{array}$} & Balanced infusion therapy \\
\hline & Cranial hypothermia \\
\hline & $\begin{array}{l}\text { Nootropic drugs: } 5-20 \mathrm{ml} \text { of } 20 \% \text { piracetam solution intravenously, } 1 \mathrm{ml} \text { of } 0.9 \% \text { sodium chloride } \\
\text { solution } 10 \mathrm{mg} \text { intramuscularly }\end{array}$ \\
\hline & Vitamin therapy \\
\hline & Hyperbaric oxygenation course \\
\hline & Symptomatic treatment of somatic complications \\
\hline
\end{tabular}

Table 4. Treatment of alcohol delirium tremens fracture and alcohol encephalopathy

Treatment of alcohol psychosis. Treatment of alcohol delirium tremens, alcohol paranoid (F10.51) and acute alcohol hallucinations (F 10.52) is given in Table 5.

Clinical picture. Premorbid traits of personality play a role in the formation of paranoid alcoholism. Thus, paranoid alcoholism is most common in individuals with hysterical and arousal premorbid traits and a tendency to generate high-value ideas.

Formation of psychosis - slowly, gradually. In the first marble, emotional tension, psychopath-like disorders in the form of suspicion increase, against this background, attitudes and jealousy develop. General somatic and. neurological disorders increase, sexual function weakens (the most characteristic symptom of prolonged alcoholism), resulting in increased sensitivity and suspicion. Then, against the background of affective disorders, ideas of attitude and jealousy develop. In the next stage of development, psychopath-like disorders turn into paranoid delusions. Criticism of the disease is lost when these disorders are accompanied by delusional ideas, numerous visual and auditory illusions, and anxiety. From this time on, the range of delusional ideas expands: the ideas of jealousy are joined by delusions of persecution or poisoning (in order to get rid of the patient). Manifestations can be retrospective: the patient confirms that his wife cheated on him many years ago, and the children are not in it. Manifestations of delusions are reflected in the patient's behavior: they look after their spouses in a very improved form, refuse food prepared by their spouses, and so on.

The distinguishing feature of paranoid delusions is that the patient is convinced of his wife's infidelity, intentional ill-treatment, and is afraid for his life. The ideas of delusion are concrete, very meaningless, nonsensical, focused on everyday topics, expanding the circle of nonexistent people, lovers, and persecutors. The intensity of the disease varies and lasts for years. The end of the disease is of two types: in some cases, organic-type personality changes increase (with a combination of cerebral atherosclerosis), in which case the nervous system breaks down; in another case - as a result of treatment, delusional ideas only become deactivated, in which case intellectual-mnestic disorders occur.

Differential diagnosis should be made with paranoid development of psychopathy, paranoid schizophrenia with atypical course. An exacerbation of the condition that facilitates differential diagnosis is that alcohol exacerbations are associated with long-term alcohol dependence

\begin{tabular}{|c|c|}
\hline Conditions & Recommended treatments \\
\hline \multirow{6}{*}{$\begin{array}{l}\text { Acute alcohol } \\
\text { hallucinations and } \\
\text { delusional psychoses }\end{array}$} & $\begin{array}{l}\text { Mainly antipsychotic neuroleptics [eg galoperidol 5-10 } \mathrm{mg} \mathrm{2-3} \mathrm{times} \mathrm{a} \mathrm{day,} \mathrm{risperidone} \\
\text { (rispolept) 4-6 mg / day] }\end{array}$ \\
\hline & $\begin{array}{l}\text { Therapy to prevent affective disorders: } 0.5 \% 2-4 \mathrm{ml} \text { of diazepam (relanium) intramuscularly or } \\
\text { intravenously in the form of drops of up to } 0.06 \mathrm{~g} / \mathrm{day} \text { or } 0.1 \% \\
\text { bromodihydrochlorphenylbenzodiazepine solution in } 1-4 \mathrm{ml} \text { intramuscularly or intravenously } \\
\text { in the form of drops of up to } 0.01 \mathrm{~g} / \text { day; }\end{array}$ \\
\hline & $\begin{array}{l}\text { Vitamin therapy; } 4 \% \text { intramuscular injection of } 5 \% \text { solution of thiamine (vitamin B): } 4 \% \\
\text { intramuscular injection of 5\% solution of pyridoxine (vitamin B6): } 1 \% \text { nicotinic acid (vitamin } \\
\text { PP) } 2 \mathrm{ml} \text { intramuscularly: } 5 \% \text { ascorbic acid nun (vitamin C) } 5 \mathrm{mi} \text { intravenously: } 2 \mathrm{ml} \text { of } \\
\text { cyanocobalamin (vitamin B12) intramuscularly. }\end{array}$ \\
\hline & $\begin{array}{l}\text { Neurometabolic therapy: picaminol } 0.05 \mathrm{~g} 3 \text { times a day; aminophenyl fatty acid (phenibut) } \\
0.25 \mathrm{~g} 3 \text { times a day }\end{array}$ \\
\hline & $\begin{array}{l}\text { Hepatoprotectors: ademethionine } 400 \mathrm{mg} \mathrm{1-2} \mathrm{times} \mathrm{a} \mathrm{day:} \mathrm{thioctic} \mathrm{acid} \mathrm{(espalipone)} 600 \mathrm{mg} \\
\text { once a day. }\end{array}$ \\
\hline & Symptomatic treatment of somatic complications \\
\hline
\end{tabular}

Table 5. Treatment of acute alcohol hallucinations and delusional 


\begin{tabular}{|c|c|}
\hline Conditions & Recommended treatments \\
\hline \multirow[t]{6}{*}{$\begin{array}{l}\text { Protargic and chronic } \\
\text { alcoholic psychoses }\end{array}$} & $\begin{array}{l}\text { Long-term antipsychotic therapy. Atypical neuroleptics: quetiapine } 150-600 \mathrm{mg} \text { / day: olanzapine 5-10 } \\
\mathrm{mg} / \mathrm{day} \text {. When the use of these drugs is not possible or ineffective, haloperidol is prescribed } 10-20 \\
\mathrm{mg} / \mathrm{day} \text {; perfenazine } 8-20 \mathrm{mg} / \mathrm{day} \text {; risperidone } 4-6 \mathrm{mg} / \text { day; stelazine } 5-15 \mathrm{mg} \text { / day } \\
25-75 \mathrm{mg} / \text { day of hydroxyzine is used in anxiety-type affective disorders }\end{array}$ \\
\hline & $\begin{array}{l}\text { Neurometabolic therapy: picaminol } 0.05 \mathrm{~g} 3 \text { times a day; aminophenyl fatty acid (phenibut) } 0.25 \mathrm{~g} 3 \\
\text { times a day }\end{array}$ \\
\hline & Intravenous means: instenon 1 tablet 3 times a day; cinnarizine $25 \mathrm{mg} 2-3$ times a day \\
\hline & Polyvitamin preparations: aerovit, complivit, glutamevit, centrum 1 dragee per day \\
\hline & Hyperbaric oxygenation course \\
\hline & Symptomatic treatment of somatic and neurological diseases \\
\hline
\end{tabular}

Treatment of chronic alcohol psychosis (F10.6, F10.7) was given in Table 6.

Table 6. Treatment of chronic alcohol psychosis

\section{Conclusion}

Beləliklə, araşdırmanın nəticələrini ümumiləşdirərək qeyd etmək lazımdır ki, məqalədə göstərilmiş tövsiyələr həm narkoloqların, psixiatrların və təcili psixiatriya yardımı göstərən həkimlər üçün masa üstü vəsaiti olmalıdır.

\section{Funding}

The article carried out by own financial resource.

\section{Author Disclosure}

Authors declare that the manuscript is submitted on behalf of all authors. None of the material in this manuscript has been published previously in any form and none of the material is currently under consideration for publication elsewhere other than noted in the cover letter to the editor. Authors declare to have any financial and personal relationship with other people or organizations that could inappropriately influence this work. All authors contributed to and have approved the final manuscript.

\section{Conflict of Interest Statement}

The authors declare that the research was conducted in the absence of any commercial or financial relationships that could be construed as a potential conflict of interest

\section{Acknowledgment}

The authors are very grateful to the staff of the Mental Health Center of the Ministry of Health of the Republic of Azerbaijan.

\section{References}

1. Hasanov Kh.A.(1964) Acute alcoholic psychoses. Baku: Publishing house of the Academy of Sciences of the Azerbaijan SSR, , 287 p.( in Azerbaijani).

2. Hasanov Kh.A.( 1973). Acute alcoholic psychoses. Baku: Maarif, 203 p. ( in Azerbaijani).Aliyev N.A, Aliyev Z N, Aliguliyev A R. (1994).Amino acid neurotransmitters in alcohol withdrawal. Alcohol Alcohol. Nov;29(6):643-7. PMID: 7695778.
3. Aliyev A.. Nadir, Zafar N Aliyev ( 2005) Application of glycine in acute alcohol hallucinosis. Hum Psychopharmacology. Dec;20(8):591-4. PMID: 16247737 doi: 10.1002/hup.735.

4. Soyka M. (1990) Psychopathological characteristics in alcohol hallucinosis and paranoid schizophrenia // Acta Psychiatry Scand, , v. 81, p. 255 - 259. 22.

5. Soyka, M. (2002) "Alcohol-Related Disorders." International Encyclopedia of the Social \& BehavioralSciences,Pergamon,2Nov.

6. American Psychiatric Association Diagnostic and statistical manual of mental disorders. 5th ed. American Psychiatric Association, Arlington 2013.

7. National Institute of Mental Health. (2016). Schizophrenia. Retrieved March 14th 2018 from

8. So YT. (2016 ).Deficiency diseases of the nervous system. In: Daroff RB, Jankovic J, Mazziotta JC, Pomeroy SL, eds. Bradley's Neurology in Clinical Practice. 7th ed. Philadelphia, PA: Elsevier; chap 85 Wernicke encephalopathy and Korsakoff syndrome are different conditions that often occur together. Both are due to brain damage caused by a lack of vitamin B1

9. Nicolaas Jm Arts , Serge Jw Walvoort, Roy Pc Kessels. (2017) Korsakoff's syndrome: a critical review. Neuropsychiatr Dis T.reat Nov 27;13:2875-2890. PMID: 29225466. PMCID: PMC5708199 doi: 10.2147/NDT.S130078.eCollection.

10. Masood, Barkat, et al.( 2017) "Treatment of Alcohol-Induced Psychotic Disorder (Alcoholic Hallucinosis)-A Systematic Review." OUP Academic, Oxford University Press, 14 Nov., www.academic.oup.com/alcalc/article/53/3/259/4627701

11. Moggi F. [Epidemiology, etiology and treatment of patients with psychosis and co-morbid substance use disorder]. Ther Umsch. 2018 Jun;75(1):37-43. PubMed.

12. Stankewicz, Holly A, et al.(2020) "Alcohol Related Psychosis." StatPearls [Internet]., U.S. National Library of Medicine, 18 Nov.,www.ncbi.nlm.nih.gov/books/NBK459134/.

13. Koppel BS.(2020) Nutritional and alcohol-related neurologic disorders. In: Goldman L, Schafer AI, eds. Goldman-Cecil Medicine. 26th ed. Philadelphia, PA: Elsevier; chap 388. 
This work is licensed under Creative Commons Attribution 4.0 License

To Submit Your Article Click Here: Submit Manuscript

DOI: $10.31579 / 2688-7517 / 027$
Ready to submit your research? Choose Auctores and benefit from:

$>$ fast, convenient online submission

$>$ rigorous peer review by experienced research in your field

$>$ rapid publication on acceptance

$>$ authors retain copyrights

$>$ unique DOI for all articles

$>$ immediate, unrestricted online access

At Auctores, research is always in progress.

Learn more auctoresonline.org/journals/addiction-research-andadolescent-behaviour 